\title{
ЗМІНИ ГЕМОПОЕЗУ В КІСТКОВОМУ МОЗКУ ТА СЕЛЕЗІНЦІ ЩУРІВ WISTAR HAN ЯК MЕХАНІЗМ ГЕМАТОТОКСИЧНОЇ ДІЇ ТЕБУКОНАЗОЛУ
}

Вступ. Однією з найбільш застосовуваних діючих речовин фрунгіцидів триазольної групи є тебуконазол. Проведені раніше дослідження перифферичної крові показали його гематотоксичну дію.

Мета дослідження - вивчити процеси кровотворення в кістковому мозку та селезінці щурів-самців Wistar Han при гострій інтоксикації тебуконазолом технічним, 97 \%.

методи дослідження. Статевозрілим щурам-самцям Wistar Han, поділеним на контрольну (0 мг/кг) та 2 експериментальні групи, одноразово внутрішньошлунково через зонд було введено токсичну дозу тебуконазолу - 1700 мг/кг маси тіла (1/2 від лд 5 ). Перифреричну кров досліджували на 0, 1, 3, 7 та 14 постекспозиційні доби. Вивчали гематологічні показники: кількісний вміст еритроцитів та ретикулоцитів, концентрацію гемоглобіну, рівень гематокриту, еритроцитарні індекси, кількість лейкоцитів $і$ тромбоцитів. Гемограму з морфологічною оцінкою клітин крові аналізували в мазках периферичної крові. Гемопоез у кістковому мозку (мієлограма) та селезінці (спленограма) досліджували на 7 і 14 постекспозиційні доби.

Результати й обговорення. Встановлено анемізуючу дію, ретикулоцитопенію та появу макрофагів у перифреричній крові. У кістковому мозку відмічено пригнічення еритропоезу з порушенням процесів гемоглобіноутворення в нормоцитах, у селезінці розвинулось екстрамедулярне кровотворення. Встановлено супресивну дію на клітини еозинофрільного та базофрільного рядів. Спостерігали компенсаторну активізацію нейтрофрілопоезу, лімсроцитопоезу та моноцитопоезу в кістковому мозку.

Висновок. Встановлено декілька механізмів гематотоксичної дії тебуконазолу технічного, $97 \%$ : порушення гемоглобіноутворення, депресію еритропоезу з патологічною регенерацією, розвиток екстрамедулярного кровотворення в селезінці та вплив на деякі ланки імунітету.

КЛЮЧОВІ СЛОВА: гемопоез; мієлограма; спленограма; екстрамедулярний еритропоез; тебуконазол; гематотоксичність.

ВСТУП. Пестициди широко використовують у всьому світі для знищення, контролю за розмноженням та попередженням появи тваринних, мікробіологічних чи рослинних шкідників. Щороку середня їх кількість, яку застосовують для обробки 1 га земельних угідь, невпинно зростає [1]. 3 одного боку, переваги пестицидів очевидні: збільшення об'єму виробництва продуктів харчування та підвищення прибутку для орермерів. 3 іншого боку, незважаючи на переваги, зростають ризики, пов'язані з їх використанням [2, 3]. 3 усього спектра пестицидів, які застосовують у світі та Європі, зокрема згідно з EUROSTAT, майже 44 \% припадає на фунгіциди [4]. В Україні ця цифра дещо менша - 23 \% (станом на 2016 р.) [5].

Найбільш поширеними представниками класу фрунгіцидів є триазольні сполуки, які використовують у сільському господарстві для зни(c) Т. В. Усенко, В. Г. Шуляк, М. Г. Проданчук, 2018. щення комплексу фрітопатогенів грибкової етіології, а також як протруйники насіння. Однією 3 найбільш застосовуваних діючих речовин фунгіцидів триазольної групи є тебуконазол (ТЕБ). На сьогодні в Переліку пестицидів і агрохімікатів, дозволених до використання в Україні, є 105 препаративних фрорм на основі ТЕБ [6].

Раніше ми провели гематологічні дослідження 10 генеричних тестових субстанцій ТЕБ від різних виробників за умов 13-тижневого субхронічного токсикологічного експерименту на лабораторних щурах Wistar Hanover (Han). Отримані результати показали розвиток анемії, лейкопенії/ лейкоцитозу в піддослідних тварин на високому (в більшості випадків) та середньому (деякі ТЕБ) рівнях доз [7]. Більш поглиблені дослідження одного з представників ТЕБ проведено при гострій інтоксикації: вивчено зміни гематологічних та цитохімічних показників периферичної крові (ПК) щурів Wistar Han. Було встановлено гемато- 
токсичну дію ТЕБ, що проявилась анемією, лейкоцитозом, компенсаторним нейтрофільозом, активізацією лімфоцитопоезу та моноцитопоезу, циркуляцією активних фрагоцитуючих макрофрагів у судинному руслі, змінами цитохімічного статусу лейкоцитів та цитотоксичним впливом на імунокомпетентні клітини [8].

Мета дослідження - вивчити процеси кровотворення в кістковому мозку та селезінці щурів-самців Wistar Han при гострій інтоксикації тебуконазолом технічним, $97 \%$.

МЕТОДИ ДОСЛІДЖЕННЯ. Було досліджено перифреричну кров та основні кровотворні органи - кістковий мозок (КМ) і селезінку. Лабораторних щурів-самців Wistar Han отримали для експерименту з розплідника Наукового токсикологічного центру імені академіка Л. І. Медведя МОЗ України. Утримували їх у контрольованих умовах конвенційного віварію (відносна вологість - 30-70\%, температура $-19-23^{\circ} \mathrm{C}$, автоматична 12-годинна система освітлення "день ніч"), вони мали необмежений доступ до корму та води. Усі маніпуляції з тваринами виконували відповідно до положень Комісії з етики медичних та біологічних досліджень Наукового токсикологічного центру імені академіка Л. І. Медведя МО3 України та Європейської конвенції про захист хребетних тварин, що використовуються для дослідних та інших наукових цілей (Страсбург, 1986) $[9,10]$. На всіх етапах гематологічних досліджень маніпуляції проводили, дотримуючись стандартних операційних процедур Центру, розроблених згідно з рекомендаціями та вимогами Належної лабораторної практики (GLP).

Після періоду акліматизації щурів до умов конвенційного віварію та перед початком експерименту в них було оцінено вхідні гематологічні показники (нульовий день досліджень) і ссрормовано групи по 5 тварин у кожній, що вірогідно не відрізнялись між собою. Дослідження проведено на статевозрілих щурах-самцях Wistar Han масою (290 20$)$ г, поділених на 3 групи: 1-ша контрольна; 2-га і 3-тя - експериментальні.

Для виконання гематологічних досліджень у гострому експерименті встановлено напівлетальну дозу (ЛД ${ }_{50}$ ) для досліджуваного генеричного ТЕБ, що становила 3400 мг/кг маси тіла. Щурам 2-ї і 3-ї груп одноразово внутрішньошлунково через зонд було введено токсичну дозу ТЕБ - 1700 мг/кг маси тіла (1/2 від ЛД $\left.{ }_{50}\right)$. Тварини 1-ї групи отримували розчинник (воду з емульгатором ОП-10 в концентрації 0,002 \%).

Перифреричну кров досліджували на 1, 3, 7 та 14 доби після експозиції ТЕБ. Кількісний вміст еритроцитів, концентрацію гемоглобіну, рівень гематокриту, еритроцитарні індекси (середній об'єм еритроцита, середній вміст гемоглобіну в одному еритроциті, середня концентрація гемоглобіну в одному еритроциті), кількість лейкоцитів і тромбоцитів визначали за допомогою ветеринарного гематологічного аналізатора "Micros ABC" ("Horiba Diagnostics", Франція).

Кількість ретикулоцитів (на 1000 еритроцитів) підраховували в мазках крові після суправітального фрарбування їх 1 \% розчином брильянтового крезилового синього у співвідношенні 1:1 [11].

Гемограму з аналізом порушень у морфології еритроцитів та лейкоцитів досліджували в мазках ПК, пофарбованих за ПаппенгеймомКрюковим [11].

У щурів 2-ї групи процеси кровотворення вивчали на 7 постекспозиційну добу (ПЕД), у тварин 3-ї групи - на 14 ПЕД.

Для отримання зразків КМ та селезінки щурів піддавали гуманній евтаназії в $\mathrm{CO}_{2}$-боксах. Кістковий мозок, вимитий з однієї стегнової кістки тварини, використовували для підрахунку загальної кількості мієлокаріоцитів [11]. 3 кісткового мозку другої стегнової кістки приготували мазки [11]. Спочатку мазки КМ переглядали під малим збільшенням мікроскопа 3 метою його якісної оцінки.

У мієлограмі було проведено дисреренційний підрахунок щонайменше 500 клітин усіх відростків кровотворення з оцінкою морфології гематопоетичних клітин та виведено результати мієлограми у відсотках. Розраховано лейкоеритробластичне (Л/Е) співвідношення, індекс дозрівання еритрокаріоцитів (ІДЕ), індекс дозрівання нейтрофрілів (ІДН), індекс дозрівання моноцитів (ІДМ) та індекс дозрівання лімфоцитів (ІДЛ) у КМ [12].

Лієнальне кровотворення - спленограму оцінювали у відбитках селезінки на предметних скельцях, пофарбованих за Паппенгеймом-Крюковим. Проведено дисреренційний аналіз щонайменше 500 спленоцитів. Розраховано Л/Е співвідношення.

Для оцінки можливості використання спільного контролю 3 метою дослідження кількісних змін як ПК, так і КМ та селезінки для термінів дослідження на 7 і 14 доби було проведено порівняльний статистичний аналіз даних загального аналізу крові в динаміці від 0 дня дослідження до 7 доби експерименту. В результаті вірогідних змін по жодному з вивчених гематологічних показників не виявлено. Тому вважаємо правомірним, науково обґрунтованим, з точки зору біоетичних підходів, використовувати меншу кількість тварин в експерименті.

Отримані дані піддавали статистичній обробці. Визначали середнє значення (М) вибірки (n), середнє квадратичне відхилення (m). Вірогідність відмінностей між показниками контроль- 
ної та експериментальних груп визначали за критерієм Стьюдента (t), а також за допомогою програми Excel. Різницю вважали достовірною при $\mathrm{p} \leq 0,05$.

РЕЗУЛЬТАТИ Й ОБГОВОРЕННЯ. ПерИферична кров. Результати дослідження показників периферичної крові щурів наведено в таблиці 1. Через добу після введення ТЕБ встановлено вірогідне зниження показника середньої концентрації гемоглобіну в одному еритроциті (на 1,2\%), при цьому кількісний вміст еритроцитів достовірно не відрізнявся від значень контролю. У той самий термін вірогідно збільшувалась

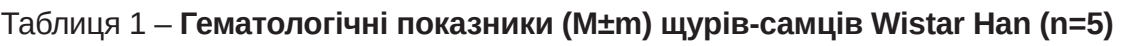
після гострої інтоксикації тебуконазолом

\begin{tabular}{|c|c|c|c|c|}
\hline \multirow[t]{2}{*}{ Показник } & \multirow{2}{*}{$\begin{array}{c}\text { Термін } \\
\text { дослідження, } \\
\text { доба } \\
\end{array}$} & 1-ша група & $\begin{array}{c}\text { 2-га група } \\
\text { (7 ПЕД) }\end{array}$ & $\begin{array}{c}\text { 3-тя група } \\
\text { (14 ПЕД) }\end{array}$ \\
\hline & & $0 \mathrm{мг/кг}$ & \multicolumn{2}{|c|}{$1700 \mathrm{Mг} / \mathrm{кг}$} \\
\hline \multirow[t]{5}{*}{ Еритроцити, 1012/л } & 0 & $7,54 \pm 0,11$ & $7,75 \pm 0,05$ & $7,98 \pm 0,15$ \\
\hline & 1 & $7,41 \pm 0,06$ & $7,64 \pm 0,03$ & $7,53 \pm 0,08$ \\
\hline & 3 & $7,54 \pm 0,09$ & $8,59 \pm 0,09^{*}$ & $8,65 \pm 0,12^{*}$ \\
\hline & 7 & $7,50 \pm 0,13$ & $7,29 \pm 0,03$ & $7,20 \pm 0,11$ \\
\hline & 14 & $7,50 \pm 0,13$ & - & $7,82 \pm 0,12$ \\
\hline \multirow[t]{5}{*}{ Гемоглобін, г/л } & 0 & $169,00 \pm 1,54$ & $171,60 \pm 1,38$ & $175,80 \pm 1,62$ \\
\hline & 1 & $172,60 \pm 1,31$ & $175,20 \pm 1,85$ & $169,20 \pm 0,85$ \\
\hline & 3 & $169,00 \pm 0,85$ & $184,40 \pm 2,54^{*}$ & $183,20 \pm 1,08^{*}$ \\
\hline & 7 & $172,60 \pm 2,54$ & $166,60 \pm 1,85$ & $163,60 \pm 1,46$ \\
\hline & 14 & $172,60 \pm 2,54$ & - & $167,50 \pm 1,38$ \\
\hline \multirow[t]{5}{*}{ Гематокрит, \% } & 0 & $42,82 \pm 0,49$ & $44,22 \pm 0,33$ & $45,44 \pm 0,46$ \\
\hline & 1 & $42,50 \pm 0,37$ & $43,66 \pm 0,31$ & $42,80 \pm 0,25$ \\
\hline & 3 & $42,70 \pm 0,35$ & $48,42 \pm 0,45^{\star}$ & $48,62 \pm 0,34^{*}$ \\
\hline & 7 & $42,92 \pm 0,78$ & $41,90 \pm 0,35$ & $40,94 \pm 0,32$ \\
\hline & 14 & $42,92 \pm 0,78$ & - & $42,84 \pm 0,55$ \\
\hline \multirow{5}{*}{$\begin{array}{l}\text { Середній об'єм } \\
\text { еритроцитів, фрл }\end{array}$} & 0 & $56,80 \pm 0,31$ & $57,20 \pm 0,23$ & $57,00 \pm 0,77$ \\
\hline & 1 & $57,20 \pm 0,38$ & $57,00 \pm 0,23$ & $57,20 \pm 0,62$ \\
\hline & 3 & $56,60 \pm 0,31$ & $56,40 \pm 0,15$ & $56,40 \pm 0,54$ \\
\hline & 7 & $57,20 \pm 0,38$ & $57,40 \pm 0,15$ & $57,00 \pm 0,54$ \\
\hline & 14 & $57,20 \pm 0,38$ & - & $55,00 \pm 0,46^{*}$ \\
\hline \multirow{5}{*}{$\begin{array}{l}\text { Середній вміст } \\
\text { гемоглобіну в одному } \\
\text { еритроциті, пг }\end{array}$} & 0 & $22,46 \pm 0,18$ & $22,10 \pm 0,12$ & $22,08 \pm 0,26$ \\
\hline & 1 & $23,30 \pm 0,13$ & $22,90 \pm 0,18$ & $22,48 \pm 0,22$ \\
\hline & 3 & $22,42 \pm 0,19$ & $21,48 \pm 0,21$ & $21,22 \pm 0,26$ \\
\hline & 7 & $23,06 \pm 0,14$ & $22,86 \pm 0,15$ & $22,74 \pm 0,22$ \\
\hline & 14 & $23,06 \pm 0,14$ & - & $21,84 \pm 0,16^{*}$ \\
\hline \multirow{5}{*}{$\begin{array}{l}\text { Середня концентрація } \\
\text { гемоглобіну в одному } \\
\text { еритроциті, г/л }\end{array}$} & 0 & $394,80 \pm 1,15$ & $387,40 \pm 0,77$ & $386,80 \pm 0,85$ \\
\hline & 1 & $405,80 \pm 0,62$ & $400,80 \pm 1,62^{*}$ & $395,00 \pm 0,92^{*}$ \\
\hline & 3 & $395,60 \pm 1,31$ & $380,60 \pm 2,38^{*}$ & $376,60 \pm 1,46^{*}$ \\
\hline & 7 & $403,00 \pm 1,38$ & $397,40 \pm 1,08$ & $399,20 \pm 0,54$ \\
\hline & 14 & $403,00 \pm 1,38$ & - & $398,20 \pm 1,69$ \\
\hline \multirow[t]{5}{*}{ Ретикулоцити, \%о } & 0 & $44,40 \pm 2,12$ & $43,60 \pm 3,38$ & $46,40 \pm 7,23$ \\
\hline & 1 & $46,60 \pm 2,38$ & $59,20 \pm 1,85^{\star}$ & $64,60 \pm 2,85^{*}$ \\
\hline & 3 & $46,60 \pm 2,69$ & $46,00 \pm 2,23$ & $49,60 \pm 1,69$ \\
\hline & 7 & $47,40 \pm 1,08$ & $15,00 \pm 0,92^{*}$ & $14,20 \pm 1,15^{*}$ \\
\hline & 14 & $47,40 \pm 1,08$ & - & $45,00 \pm 1,54$ \\
\hline \multirow[t]{5}{*}{ Тромбоцити, 109/л } & 0 & $829,00 \pm 11,46$ & $872,20 \pm 6,77$ & $817,20 \pm 17,38$ \\
\hline & 1 & $871,80 \pm 10,77$ & $862,20 \pm 10,54$ & $869,20 \pm 11,85$ \\
\hline & 3 & $876,20 \pm 7,69$ & $815,40 \pm 13,77$ & $870,80 \pm 9,15$ \\
\hline & 7 & $718,00 \pm 12,85$ & $881,60 \pm 7,08^{*}$ & $829,20 \pm 14,00^{*}$ \\
\hline & 14 & $718,00 \pm 12,85$ & - & $606,40 \pm 25,92^{*}$ \\
\hline \multirow[t]{5}{*}{ Лейкоцити, 109/л } & 0 & $12,88 \pm 0,36$ & $13,26 \pm 0,30$ & $11,96 \pm 0,47$ \\
\hline & 1 & $14,26 \pm 0,31$ & $13,04 \pm 0,49$ & $12,30 \pm 0,50$ \\
\hline & 3 & $15,50 \pm 0,43$ & $23,82 \pm 3,91$ & $16,48 \pm 0,52$ \\
\hline & 7 & $15,08 \pm 0,62$ & $16,54 \pm 0,38$ & $15,96 \pm 0,75$ \\
\hline & 14 & $15,08 \pm 0,62$ & - & $15,58 \pm 0,77$ \\
\hline
\end{tabular}

Примітка. Тут і в таблицях 2-4:

1. $\mathrm{n}$ - кількість тварин у групі.

2. * - статистично вірогідні зміни при $p \leq 0,05$. 
кількість ретикулоцитів у ПК (на 27 \%). Підвищене надходження з кісткового мозку в циркулюючу кров молодих незрілих еритроцитів - ретикулоцитів - спричинене, на нашу думку, гіпоксичним станом організму після інтоксикації фрунгіцидом і $є$ компенсаторною реакцією організму.

На 3 ПЕД У щурів вірогідно збільшувались кількість еритроцитів (на $14 \%$ ), вміст гемоглобіну (на $9 \%$ ) та рівень гематокриту (на $13 \%$ ). Достовірно знижувались еритроцитарні індекси: середній вміст гемоглобіну в одному еритроциті (на 4,2 \%) та середня концентрація гемоглобіну в одному еритроциті (на 3,8\%). Кількість ретикулоцитів не відрізнялась від значень контролю. Еритроцитоз у ПК мав адаптивний характер після гіпоксії, яку відзначали на 1 ПЕД.

На 7 ПЕД У щурів експериментальної групи було зафріксовано тенденцію до зниження як вмісту гемоглобіну (на 3,5 \%), так і рівня гематокриту (на 2,4 \%). Кількість еритроцитів вірогідно не змінювалась відносно значень контролю. Середня концентрація гемоглобіну в одному еритроциті достовірно зменшувалась (на 0,9\%). При цьому в ПК засріксовано ретикулоцитопенію: значне вірогідне зниження кількості ретикулоцитів (на 69 \%). Оскільки дані клітини є перехідними формами між нормоцитами, що утворюються в КМ, та еритроцитами, які циркулюють у ПК, то за зміною їх кількості можна оцінювати есрективність еритропоезу в КМ. Таким чином, згідно 3 нашими результатами, встановлено, що діяльність червоного кісткового мозку в часовому проміжку від 4 до 7 ПЕД була пригніченою.

На 14 ПЕД У тварин тенденція до зниження гемоглобіну зберігалась. Кількість еритроцитів вірогідно не змінювалась порівняно з контролем. Встановлено достовірне зниження індексів: середнього об'єму еритроцитів (на 4 \%) та середнього вмісту гемоглобіну в одному еритроциті (на 5,3\%). У цей термін вірогідно зменшувалась кількість тромбоцитів (майже на $16 \%$ ).

Варто зазначити, що у всі терміни дослідження в мазках ПК відмічали появу поліхроматофрільних (ПХН) та оксифрільних нормоцитів кісткового мозку. Найбільше попередників еритроцитів спостерігали на 3 ПЕД. Еритрокаріоцити мали як нормальні морсоологічні особливості, так і патологічні: з мікроядрами (ПХН), бінуклеарні, з каріорексисом та порушеннями енуклеації ядра. Такі зміни в морфології підтверджують цитотоксичну дію ТЕБ на клітини еритроцитарного ряду в КМ [8].

Загалом отримані результати щодо змін червоної крові показали анемізуючу дію тебуконазолу.

Лейкограма. Результати аналізу лейкограми наведено в таблиці 2. Уже на 1 ПЕД у щурів експериментальної групи було відмічено вірогідне підвищення загальної кількості клітин нейтрофільного ряду (на 53 \%) за рахунок зрілих форм сегментоядерних нейтрофрілів. На 3 ПЕД встановлено достовірне зростання загальної кількості нейтрофілів за рахунок як паличкоядерних (на 43,7 \%), так і сегментоядерних (на 81,6 \%) срорм. До 7 доби експерименту кількість паличкоядерних нейтрофрілів залишалась усе ще вірогідно збільшеною (на 29 \%). Морсоологічна оцінка клітин цього ряду показала, що в ПК зростала кількість гіперсегментованих нейтрофрілів: найбільше їх відмічено на 3 та 7 ПЕД. Даний процес, на нашу думку, пов'язаний з демаргінацією клітин із судинного пристінкового пулу в циркулюючий, і його розцінюють як захисний механізм. Загалом нейтрофрілія та лівий зсув у ПК $є$ наслідком активації нейтрофрілопоезу в КМ та компенсаторною реакцією організму щурів у відповідь на анемію після інтоксикації ТЕБ.

Встановлено відносну лімфоцитопенію: чисельність лімфоцитів вірогідно знижувалась (на 17,4 \%) лише на 3 ПЕД. I в цей же термін достовірно зростала кількість моноцитів (на $40 \%$ ). У циркулюючому руслі на 3 та 7 ПЕД відмічено появу макрофрагів. Морфологічно ці клітини були в стадії активного фрагоцитозу: вакуолізовані, містили в цитоплазмі залишки зруйнованих клітинних компонентів.

Зміни еозинофрільного ряду проявились незначним, але достовірним, зниженням (на $33 \%$ ) кількості еозинофілів лише на 7 ПЕД.

До 14 ПЕД у лейкограмі вірогідно нижчою була тільки кількість еозинофрілів (на 38 \%). Усі інші досліджені гематологічні показники достовірно не відрізнялись від значень контролю.

Загальна кількість мієлокаріоцитів, мієлограма. Дослідження кісткового мозку проводили на 7 добу після експозиції ТЕБ для щурів 2-ї групи та на 14 добу для тварин 3-ї групи. Його результати наведено в таблиці 3. Візуальна оцінка препаратів кісткового мозку під малим збільшенням мікроскопа показала, що розподіл клітин у КМ щурів обох експериментальних груп не відрізнявся від контролю і був рівномірним, нормоклітинним, без патологічних елементів, скупчень та комплексів клітин, жирового заміщення мієлоцитів з однорідною наявністю мегакаріоцитів.

7 ПЕД. Загальна кількість мієлокаріоцитів достовірно зростала (на 34 \%) відносно значень контролю. Це вказувало на підвищену їх проліфрерацію.

Підрахунок мієлограми показав, що загальна кількість клітин еритрону вірогідно не змінювалась. Однак встановлено достовірне збільшення кількості еритробластів (у 9 разів). Також відмі- 


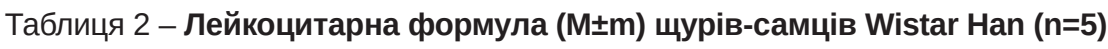
після гострої інтоксикації тебуконазолом

\begin{tabular}{|c|c|c|c|c|}
\hline \multirow[t]{2}{*}{ Показник, \% } & \multirow{2}{*}{$\begin{array}{c}\text { Термін } \\
\text { дослідження, } \\
\text { доба }\end{array}$} & 1-ша група & $\begin{array}{c}\text { 2-га група } \\
\text { (7 ПЕД) }\end{array}$ & $\begin{array}{c}\text { 3-тя група } \\
\text { (14 ПЕД) }\end{array}$ \\
\hline & & $0 \mathrm{мг} / \mathrm{к} \Gamma$ & \multicolumn{2}{|c|}{$1700 \mathrm{мг/кг}$} \\
\hline \multirow{4}{*}{$\begin{array}{l}\text { Нейтрофрільні } \\
\text { метамієлоцити }\end{array}$} & 1 & - & - & - \\
\hline & 3 & - & - & - \\
\hline & 7 & $1,00 \pm 0$ & $1,00 \pm 0$ & - \\
\hline & 14 & $1,00 \pm 0$ & - & \\
\hline \multirow{4}{*}{$\begin{array}{l}\text { Паличкоядерні } \\
\text { нейтрофріли }\end{array}$} & 1 & $2,00 \pm 0,15$ & $1,75 \pm 0,15$ & $1,00 \pm 0^{*}$ \\
\hline & 3 & $1,67 \pm 0,08$ & $2,40 \pm 0,23^{*}$ & $2,80 \pm 0,23^{*}$ \\
\hline & 7 & $1,75 \pm 0,15$ & $2,25 \pm 0,08^{*}$ & $1,00 \pm 0^{*}$ \\
\hline & 14 & $1,75 \pm 0,15$ & - & $2,20 \pm 0,23$ \\
\hline \multirow{4}{*}{$\begin{array}{l}\text { Сегментоядерні } \\
\text { нейтрофріли }\end{array}$} & 1 & $12,20 \pm 0,92$ & $18,60 \pm 1,46^{*}$ & $8,80 \pm 0,69^{*}$ \\
\hline & 3 & $9,80 \pm 0,62$ & $17,80 \pm 0,62^{*}$ & $23,00 \pm 1,38^{*}$ \\
\hline & 7 & $10,40 \pm 0,92$ & $10,00 \pm 0,54$ & $7,80 \pm 0,69$ \\
\hline & 14 & $10,40 \pm 0,92$ & - & $8,40 \pm 0,69$ \\
\hline \multirow{4}{*}{$\begin{array}{l}\text { Загальна кількість } \\
\text { нейтрофрілів }\end{array}$} & 1 & $14,2 \pm 1,07$ & $20,35 \pm 1,61^{*}$ & $9,80 \pm 0,69$ \\
\hline & 3 & $11,47 \pm 0,7$ & $20,2 \pm 0,85^{*}$ & $25,80 \pm 1,61^{*}$ \\
\hline & 7 & $13,15 \pm 1,1$ & $13,25 \pm 0,62$ & $8,80 \pm 0,69$ \\
\hline & 14 & $13,15 \pm 1,1$ & - & $10,60 \pm 0,92$ \\
\hline \multirow[t]{4}{*}{ Еозинофріли } & 1 & $1,50 \pm 0,08$ & $1,33 \pm 0,08$ & - \\
\hline & 3 & $1,00 \pm 0$ & - & - \\
\hline & 7 & $2,25 \pm 0,15$ & $1,50 \pm 0,08^{*}$ & $2,00 \pm 0$ \\
\hline & 14 & $2,25 \pm 0,15$ & - & $1,40 \pm 0,08^{*}$ \\
\hline \multirow[t]{4}{*}{ Базофріли } & 1 & - & - & - \\
\hline & 3 & - & - & - \\
\hline & 7 & - & - & - \\
\hline & 14 & - & - & - \\
\hline \multirow[t]{4}{*}{ Моноцити } & 1 & $9,80 \pm 0,85$ & $7,60 \pm 0,54$ & $7,80 \pm 1,00$ \\
\hline & 3 & $10,60 \pm 0,85$ & $14,80 \pm 1,15^{*}$ & $12,20 \pm 1,31$ \\
\hline & 7 & $8,80 \pm 0,85$ & $12,00 \pm 1,38$ & $8,00 \pm 0,85$ \\
\hline & 14 & $8,80 \pm 0,85$ & - & $10,40 \pm 0,46$ \\
\hline \multirow[t]{4}{*}{ Лімфроцити } & 1 & $75,60 \pm 1,00$ & $71,60 \pm 1,54$ & $82,00 \pm 1,69$ \\
\hline & 3 & $78,40 \pm 1,31$ & $64,80 \pm 1,38^{*}$ & $61,80 \pm 2,31^{*}$ \\
\hline & 7 & $77,40 \pm 1,46$ & $74,80 \pm 0,85$ & $82,80 \pm 1,08^{*}$ \\
\hline & 14 & $77,40 \pm 1,46$ & - & $77,60 \pm 0,85$ \\
\hline
\end{tabular}

чено тенденції до зростання числа пронормоцитів (на $54 \%$ ) та базофрільних нормоцитів (на 23 \%). Для оцінки процесів еритропоезу обчислено ІДЕ, який показує співвідношення гемоглобінізованих фрорм нормоцитів до загальної кількості еритрокаріоцитів у КМ. У результаті встановлено достовірне зниження ІДЕ (на $12 \%$ ), що свідчило про гальмування еритропоезу на стадіях поліхроматофільних та оксифрільних нормоцитів. Цей фракт підтвердився ретикулоцитопенією в ПК. Зменшення вмісту гемоглобіну в ПК було, відповідно, наслідком порушення процесів гемоглобіноутворення в КМ.

При морорологічному аналізі препаратів КМ було відмічено наявність патологічних фрорм поліхроматофрільних нормоцитів, що свідчило про порушення процесів поділу: бінуклеарні клітини, які мали непропорційний розмір новоутворених ядер, ПХН з мікроядрами та ядерними бруньками. Також були присутні клітини 3 каріорексисом. Виявлені порушення в морфології мають дегенеративний характер, є ознакою патологічної регенерації клітин внаслідок токсичної дії ТЕБ.

Загальна кількість клітин нейтрофрільного ряду вірогідно не відрізнялась від значень контролю. Але підвищувалась кількість окремих попередників цього відростка, зокрема нейтрофрільних мієлобластів $(2,4 \pm 1,1$; в контролі $0,4 \pm 0,2)$, промієлоцитів $(13,0 \pm 3,0$; в контролі $7,4 \pm 1,7)$, та достовірно зростав вміст нейтрофрільних мієлоцитів (на 69 \%). Кількість паличкота сегментоядерних нейтрофрілів у КМ вірогідно не змінювалась. Дещо підвищувалась кількість лейкоцитів у стані мітозу. Індекс дозрівання нейтрофрілів, що характеризує стан клітин гранулоцитарного ряду, достовірно збільшувався (на $59 \%$ ), що повністю підтверджувало активний нейтрофрілопоез у КМ. Ранні попередники клітин нейтросрільного ряду були підвищеними, але відсутність змін загальної кількості нейтрофрілоцитів, паличко- та сегментоядерних нейтрофрілів разом зі зростанням останніх у ПК вказувала на активне вимивання цих клітин у судинне русло. 
Лейкоеритробластичне співвідношення в цей термін підвищувалось (табл. 3). Зростання даного індексу, з одного боку, відбувалося внаслідок еритросупресії в КМ, а з іншого - свідчило про гіперплазію нейтрофрілоцитів унаслідок стимуляції нейтросрільного гранулоцитопоезу в KM, що є компенсаторною реакцією організму у відповідь на анемію в результаті дії ТЕБ.

У КМ відмічено тенденції до зменшення клітин еозинофрільного ряду: нижчою, зокрема, була кількість еозинофрільних промієлоцитів (на 40 \%) та метамієлоцитів (на 75 \%). Також спо- стерігали тенденцію до зменшення і клітин базофільного ряду (на 72 \%). Одночасно з відносною еозинопенією в ПК таке пригнічення вищезазначених відростків кровотворення може вказувати на порушення імунних процесів в організмі після гострої інтоксикації ТЕБ.

На 7 добу експерименту вірогідно збільшувалась загальна кількість клітин моноцитарного ряду (на 68 \%). Зростала кількість монобластів $(0,2 \pm 0,1 ;$ в контролі - 0,1 $\pm 0,1)$ та промоноцитів, число яких було достовірно вищим (на $92 \%$ ). Індекс дозрівання моноцитів був дещо збільше-

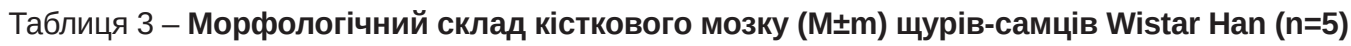
після гострої інтоксикації тебуконазолом (мієлограма)

\begin{tabular}{|c|c|c|c|}
\hline \multirow{2}{*}{ Параметр, \% } & 1-ша група & 2-га група (7 ПЕД) & 3-тя група (14 ПЕД) \\
\hline & $0 \mathrm{Mr} / \mathrm{k} \Gamma$ & \multicolumn{2}{|c|}{$1700 \mathrm{Mг} / \mathrm{\kappa г}$} \\
\hline Недифреренційовані бласти & $0,03 \pm 0,04$ & 0 & 0 \\
\hline Еритробласти & $0,07 \pm 0,07$ & $0,63 \pm 0,12^{*}$ & $0,23 \pm 0,07$ \\
\hline Пронормоцити & $0,79 \pm 0,29$ & $1,16 \pm 0,21$ & $0,97 \pm 0,22$ \\
\hline Нормоцити базофрільні & $7,26 \pm 0,39$ & $8,68 \pm 1,34$ & $8,23 \pm 1,99$ \\
\hline Нормоцити поліхроматофрільні & $17,04 \pm 1,25$ & $15,13 \pm 1,98$ & $16,02 \pm 3,58$ \\
\hline Нормоцити оксиорільні & $2,16 \pm 0,29$ & $1,92 \pm 0,46$ & $2,54 \pm 0,55$ \\
\hline Загально еритрокаріоцитів & $27,32 \pm 1,86$ & $27,52 \pm 3,98$ & $27,99 \pm 6,28$ \\
\hline Мієлобласти нейтрофрільні & $0,07 \pm 0,04$ & $0,38 \pm 0,16$ & $0,16 \pm 0,07$ \\
\hline Промієлоцити нейтрофрільні & $1,21 \pm 0,29$ & $2,08 \pm 0,50$ & $2,05 \pm 0,69$ \\
\hline Мієлоцити нейтрофрільні & $2,31 \pm 0,49$ & $3,76 \pm 0,36^{*}$ & $2,95 \pm 0,45$ \\
\hline Метамієлоцити нейтрофрільні & $4,52 \pm 0,79$ & $6,02 \pm 0,73$ & $3,93 \pm 0,97$ \\
\hline Паличкоядерні нейтрофріли & $4,30 \pm 0,72$ & $4,90 \pm 0,69$ & $3,29 \pm 0,58$ \\
\hline Сегментоядерні нейтрофріли & $7,11 \pm 1,00$ & $6,48 \pm 1,26$ & $7,94 \pm 0,77$ \\
\hline Загально нейтросрілоцитів & $19,52 \pm 2,86$ & $23,63 \pm 2,94$ & $20,33 \pm 2,54$ \\
\hline Промієлоцити еозинофрільні & $0,73 \pm 0,18$ & $0,41 \pm 0,08$ & $0,36 \pm 0,14$ \\
\hline Мієлоцити еозинофрільні & $1,12 \pm 0,09$ & $1,05 \pm 0,16$ & $0,55 \pm 0,18^{*}$ \\
\hline Метамієлоцити еозиносрільні & $0,27 \pm 0,18$ & $0,07 \pm 0,04$ & $0,58 \pm 0,18$ \\
\hline Паличкоядерні еозинофріли & $0,07 \pm 0,07$ & 0 & $0,53 \pm 0,09^{*}$ \\
\hline Сегментоядерні еозинофріли & 0 & 0 & 0 \\
\hline Загально еозинофрілоцитів & $2,18 \pm 0,45$ & $1,53 \pm 0,20$ & $2,02 \pm 0,34$ \\
\hline Монобласти & $0,10 \pm 0,07$ & $0,22 \pm 0,10$ & $0,16 \pm 0,07$ \\
\hline Промоноцити & $1,27 \pm 0,25$ & $2,37 \pm 0,35^{\star}$ & $1,64 \pm 0,27$ \\
\hline Моноцити & $1,6 \pm 0,29$ & $2,24 \pm 0,36$ & $4,07 \pm 0,68^{*}$ \\
\hline Загально моноцитарних клітин & $2,97 \pm 0,43$ & $4,83 \pm 0,68$ & $5,88 \pm 0,84^{*}$ \\
\hline Мастоцити & $0,20 \pm 0,14$ & $0,59 \pm 0,42$ & $0,22 \pm 0,14$ \\
\hline Лімфоблласти & $0,26 \pm 0,06$ & $0,51 \pm 0,21$ & $0,23 \pm 0,14$ \\
\hline Пролімфоцити & $4,68 \pm 0,36$ & $6,91 \pm 0,97^{*}$ & $5,14 \pm 0,46$ \\
\hline Лімфоцити & $29,97 \pm 3,53$ & $29,43 \pm 5,00$ & $37,54 \pm 4,99$ \\
\hline Загально лімфооцитарних клітин & $34,91 \pm 3,38$ & $36,86 \pm 6,07$ & $42,91 \pm 5,03$ \\
\hline Мегакаріоцити & $0,13 \pm 0,04$ & $0,03 \pm 0,04$ & $0,13 \pm 0,04$ \\
\hline Базофріли & $0,96 \pm 0,39$ & $0,25 \pm 0,13$ & $0,09 \pm 0,10$ \\
\hline Плазмобласти & $0,03 \pm 0,03$ & $0,13 \pm 0,04$ & $0,10 \pm 0,07$ \\
\hline Проплазмоцити & $0,20 \pm 0,11$ & $0,19 \pm 0,11$ & $0,25 \pm 0,16$ \\
\hline Плазмоцити & $0,10 \pm 0,07$ & $0,09 \pm 0,06$ & 0 \\
\hline Загально плазматичних клітин & $0,33 \pm 0,18$ & $0,41 \pm 0,18$ & $0,35 \pm 0,16$ \\
\hline Клітини мітозу еритрокаріоцитів & 0 & $0,03 \pm 0,03$ & $0,07 \pm 0,04$ \\
\hline Клітини мітозу лейкоцитів & $0,13 \pm 0,04$ & $0,38 \pm 0,14$ & $0,45 \pm 0,21$ \\
\hline Макрофраги & $0,06 \pm 0,04$ & $0,03 \pm 0,04$ & $0,22 \pm 0,07$ \\
\hline Л/Е співвідношення & $2,28 \pm 0,22$ & $2,61 \pm 0,39$ & $3,00 \pm 0,53$ \\
\hline ІДЕ & $0,70 \pm 0,01$ & $0,62 \pm 0,02^{*}$ & $0,67 \pm 0,01$ \\
\hline ІДН & $0,70 \pm 0,04$ & $1,11 \pm 0,09^{*}$ & $0,80 \pm 0,13$ \\
\hline ІДМ & $0,89+0,14$ & $1,19+0,17$ & $0,46+0,07^{\star}$ \\
\hline ІДЛ & $0,18+0,03$ & $0,27+0,02^{*}$ & $0,16+0,02$ \\
\hline Загальна кількість мієлокаріоцитів $\left(10^{6}\right)$ & $36,84 \pm 1,99$ & $49,22 \pm 1,72^{*}$ & $34,71 \pm 1,39$ \\
\hline
\end{tabular}


ним $(1,19 \pm 0,17$; в контролі $-0,89 \pm 0,14)$. Це свідчило про активацію моноцитопоезу. Даний фракт разом із моноцитозом та появою активних макрофрагів у ПК можна пояснити підвищеною потребою в клітинах з фрагоцитарними властивостями в кров'яному руслі.

Загальна кількість клітин лімфоїдного ряду вірогідно не відрізнялась від значень контролю. Але на 7 ПЕД у КМ піддослідних тварин зростала кількість лімсробластів $(3,2 \pm 1,3$; в контролі $1,6 \pm 0,4)$, достовірно підвищувалась кількість пролімфоцитів (на 52 \%). Поряд із цим, відмічено тенденцію до збільшення числа плазмобластів $(0,8 \pm 0,2$; в контролі $-0,2 \pm 0,2)$. Індекс дозрівання лімфроїдних елементів вірогідно зростав $(0,27 \pm 0,02 ;$ в контролі - 0,18 $\pm 0,03)$. Усе це вказувало на омолодження даного відростка кровотворення. Тобто відбувалась активізація лімфоцитарного відростка кровотворення. Тому відносна лімсроцитопенія в ПК, описана вище, з подальшим лімсроцитозом у КМ мала компенсаторний характер.

14 ПЕД. У щурів загальна кількість мієлокаріоцитів, загальна кількість еритрокаріоцитів та окремих їх елементів вірогідно не відрізнялись від значень контролю. Але вищою, порівняно 3 контролем, була кількість еритробластів (у 3,5 раза), пронормоцитів (на $25 \%$ ) та базофрільних нормоцитів (на $15 \%$ ). Спостерігали деяке зростання числа фрігур мітозу еритрокаріоцитів та незначне зниження ІДЕ. Лейкоеритробластичне співвідношення дещо збільшувалось, що вказувало на зменшену проліферацію клітин еритрону. Тобто до 14 ПЕД у КМ все ще відмічали кількісні зміни клітинного складу, які було відзначено на 7 ПЕД, але вони мали менш виражений характер. Все вищезазначене разом зі зниженням гемоглобіну в ПК свідчило про те, що до цього терміну ще залишалися порушеними процеси дозрівання та гемоглобінізації нормоцитів. Відновитись КМ після еритросупресії до 14 доби після гострої інтоксикації ТЕБ повністю не вдалося.

Загальна кількість клітин нейтрофрільного ряду, а також число нейтрофрілів на всіх стадіях дозрівання вірогідно не відрізнялись від значень контролю.

Загальна кількість клітин еозинофільного ряду достовірно не відрізнялась від значень контролю. Але відмічено вірогідне зниження кількості еозиносрільних мієлоцитів (на $50 \%$ ) та, водночас, встановлено тенденцію до підвищення числа еозинофрільних метамієлоцитів (у 2,5 раза) і достовірне зростання їх паличкоядерних фрорм (у 8,5 раза). На нашу думку, незначне зменшення ранніх попередників еозинофілів у КМ та незначна еозинопенія в ПК є ознакою слабкої супресії цього відростка кровотворення. Також залишалась значно нижчою від контрольного значення і кількість клітин базофрільного ряду (майже на 90 \%). Встановлена на 7 ПЕД супресія базофрільного ряду стала глибшою до 14 ПЕД. На нашу думку, еозинопенія і базопенія в КМ $€$ проявом токсичної дії ТЕБ на ці відростки кровотворення та ознакою порушення імунних процесів в організмі.

Загальна кількість клітин моноцитарного ряду в цей термін достовірно підвищувалась за рахунок вірогідного зростання зрілих форм моноцитів (у 2,6 раза). Відповідно, ІДМ у цей термін вірогідно знижувався (на 48 \%). У мазках КМ щурів експериментальної групи відмічено появу поодиноких макрофрагів. Таке явище свідчило про потребу КМ у фрагоцитарних клітинах для очищення його від патологічно змінених клітинних компонентів, зокрема поліхроматофрільних нормоцитів, та дозволило попередити надходження таких клітин у ПК.

Загальна кількість лімсооцитарних клітин дещо зростала (на 27 \%) за рахунок зрілих фрорм лімсроцитів. Індекс дозрівання лімфоцитів вірогідно не відрізнявся від значень контролю.

Спленограма. Дані дослідження спленограми щурів наведено в таблиці 4. У результаті достовірних змін загальної кількості клітин лімфоцитарного, нейтрофрільного та еозинофрільного рядів не спостерігали в обидва терміни дослідження.

Загальна кількість клітин моноцитарного ряду зростала (у 2,8 раза) тільки на 7 ПЕД. Також підвищувалось число промоноцитів (у 4,7 раза) та моноцитів (у 2,3 раза). До 14 ПЕД кількісні значення цих клітин суттєво не відрізнялись від контрольних.

Але на 7 та 14 ПЕД значно, хоча і не достовірно, підвищувалась загальна кількість клітин еритрону (на 50 \%) відносно значень контролю. Відповідно, на 7 ПЕД у спленограмі з'являлись еритрокаріоцити різного ступеня зрілості. Вірогідно зростало число еритробластів $(0,12 \pm 0,04$; в контролі - 0) та пронормоцитів $(0,32 \pm 0,04$; в контролі-0), відмічено тенденції до збільшення кількості базофільних (у 2,5 раза), поліхроматофрільних (на $18 \%$ ) та оксифрільних (майже у 2 рази) нормоцитів. На 14 ПЕД еритробласти та пронормоцити були відсутні, але зростала кількість базофрільних (у 4,7 раза), поліхроматофрільних (на $13 \%$ ) та оксифрільних (у 2,3 раза) нормоцитів. В обидва терміни Л/Е співвідношення в спленограмі знижувалось (майже у 2 рази).

Зниження Л/Е співвідношення разом зі збільшенням загальної кількості клітин еритрону за рахунок ранніх попередників підтверджувало гіперплазію еритроїдних елементів у селезінці. 


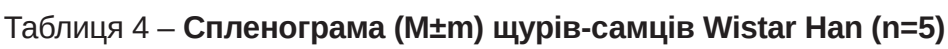
після гострої інтоксикації тебуконазолом

\begin{tabular}{|c|c|c|c|}
\hline \multirow{2}{*}{ Параметр, \% } & 1-ша група & 2-га група (7 ПЕД) & "3-тя група (14 ПЕД) \\
\hline & $0 \mathrm{Mг} / \mathrm{kг}$ & \multicolumn{2}{|c|}{$1700 \mathrm{Mr} / \mathrm{Kг}$} \\
\hline Недифреренційовані бласти & 0 & 0 & 0 \\
\hline Лімсообласти & $0,24 \pm 0,09$ & $0,36 \pm 0,04$ & $0,08 \pm 0,04$ \\
\hline Пролімсроцити & $4,08 \pm 0,82$ & $6,72 \pm 1,46$ & $2,60 \pm 0,77$ \\
\hline Лімфоцити & $89,28 \pm 1,72$ & $81,08 \pm 4,08$ & $86,80 \pm 3,52$ \\
\hline Загально лімсооцитарних клітин & $93,60 \pm 1,42$ & $88,16 \pm 3,91$ & $89,48 \pm 3,52$ \\
\hline Еритробласти & 0 & $0,12 \pm 0,04^{*}$ & 0 \\
\hline Пронормоцити & 0 & $0,32 \pm 0,04^{*}$ & 0 \\
\hline Нормоцити базосрільні & $0,52 \pm 0,26$ & $1,92 \pm 0,6$ & $2,44 \pm 0,94$ \\
\hline Нормоцити поліхроматофрільні & $5,84 \pm 1,72$ & $6,92 \pm 2,49$ & $6,60 \pm 2,06$ \\
\hline Нормоцити оксифрільні & $0,64 \pm 0,3$ & $1,24 \pm 0,52$ & $1,48 \pm 0,39$ \\
\hline Загально еритрокаріоцитів & $7,00 \pm 1,59$ & $10,52 \pm 3,3$ & $10,52 \pm 2,88$ \\
\hline Мієлобласти нейтрофрільні & 0 & 0 & 0 \\
\hline Промієлоцити нейтрофрільні & 0 & 0 & 0 \\
\hline Мієлоцити нейтросрільні & 0 & 0 & 0 \\
\hline Метамієлоцити нейтрофрільні & 0 & 0 & 0 \\
\hline Паличкоядерні нейтрофріли & $0,12 \pm 0,13$ & $0,08 \pm 0,04$ & $0,04 \pm 0,04$ \\
\hline Сегментоядерні нейтрофріли & $0,16 \pm 0,09$ & $0,20 \pm 0,13$ & $0,44 \pm 0,21$ \\
\hline Загально нейтрофрілоцитів & $0,28 \pm 0,17$ & $0,28 \pm 0,13$ & $0,48 \pm 0,21$ \\
\hline Промієлоцити еозинофрільні & 0 & 0 & 0 \\
\hline Мієлоцити еозиносрільні & 0 & 0 & 0 \\
\hline Метамієлоцити еозинофрільні & 0 & 0 & 0 \\
\hline Паличкоядерні еозинофріли & 0 & $0,08 \pm 0,04$ & 0 \\
\hline Сегментоядерні еозинофріли & 0 & 0 & $0,04 \pm 0,04$ \\
\hline Загально еозиносрілоцитів & 0 & $0,08 \pm 0,04$ & $0,04 \pm 0,04$ \\
\hline Монобласти & 0 & 0 & 0 \\
\hline Промоноцити & $0,12 \pm 0,04$ & $0,56 \pm 0,26$ & $0,08 \pm 0,09$ \\
\hline Моноцити & $0,48 \pm 0,17$ & $1,12 \pm 0,43$ & $0,36 \pm 0,17$ \\
\hline Загально моноцитарних клітин & $0,60 \pm 0,21$ & $1,68 \pm 0,56$ & $0,44 \pm 0,26$ \\
\hline Плазмобласти & $0,04 \pm 0,04$ & $0,04 \pm 0,04$ & 0 \\
\hline Проплазмоцити & $0,16 \pm 0,17$ & $0,08 \pm 0,04$ & 0 \\
\hline Плазмоцити & $0,24 \pm 0,17$ & $0,32 \pm 0,13$ & 0 \\
\hline Загально плазматичних клітин & $0,44 \pm 0,39$ & $0,4 \pm 0,13$ & 0 \\
\hline Мастоцити & 0 & 0 & 0 \\
\hline Базофріли & 0 & 0 & 0 \\
\hline Макрофраги & 0 & 0 & $1,00 \pm 1,07$ \\
\hline Мегакаріоцити & 0 & 0 & 0 \\
\hline Л/Е співвідношення & $20,03 \pm 9,48$ & $11,89 \pm 4,35$ & $10,34 \pm 2,1$ \\
\hline
\end{tabular}

Поява молодих ядерних форм еритроцитарного відростка (еритробластів, пронормоцитів, базофрільних, поліхроматофрільних та оксифрільних нормоцитів) у спленограмі вказувала на розвиток екстрамедулярного кровотворення в цьому органі. Екстрамедулярний еритропоез у селезінці розвинувся внаслідок еритросупресії і неефективного еритропоезу в КМ та направлений на компенсацію анемічних проявів у ПК після гострої інтоксикації ТЕБ.

ВИСНОВКИ. 1. Встановлено декілька механізмів гематотоксичної дії тебуконазолу: порушення гемоглобіноутворення, депресію еритропоезу з патологічною регенерацією, розвиток екстрамедулярного кровотворення в селезінці та вплив на деякі ланки імунітету.

2. Механізм анемізуючої дії полягає в гальмуванні еритропоезу в кістковому мозку на стадіях поліхроматофрільних та оксифрільних нормоцитів, що призводить до порушення процесів гемоглобіноутворення і патологічної регенерації еритрону.

3. Внаслідок еритросупресії та неефективного еритропоезу в кістковому мозку в селезінці розвивається замісний екстрамедулярний еритропоез, який компенсує кількість еритроцитів у периферичній крові.

4. У відповідь на незворотну анемію ТЕБ викликає активацію нейтрофрілопоезу в КМ та нейтросрілію в ПК, що є компенсаторною реакцією організму щурів.

5. Активізація лімфроцитопоезу в КМ направлена на компенсацію лімфоцитопенії в ПК.

6. При дії досліджуваної речовини в периферичній крові циркулює значна кількість макрофрагів із залишками зруйнованих клітинних компонентів. Активізація моноцитопоезу та на- 
явність макрофрагів у КМ спрямовані на очищення крові від патологічних целюлярних елементів.

7. Тебуконазол призводить до слабкої супресії еозинофрілопоезу та значного пригнічення клітин базофрільного ряду в КМ, що проявляється еозинопенією і повною відсутністю базофрілів у ПК та свідчить про порушення імунних процесів в організмі щурів.

\section{СПИСОК ЛІТЕРАТУРИ}

1. Михайленко О. Г. Аналіз світового ринку сільськогосподарської продукції різних видів виробництва в контексті вимог концепції сталого розвитку [Електронний ресурс] / О. Г. Михайленко // Агросвіт. - 2016. № (4). - С. 43-52. - Режим доступу : http://nbuv.gov. ua/UJRN/agrosvit_2016_4_9.

2. Cunningham M. Use of pesticides: benefits and problems associated with pesticides / M. Cunningham // Food and Chemical Toxicology. - 2015. - 43 (2). P. 261-269. - Mode access: www.study.com/academy vegetables for high lipophilic organochlorine pesticide (OCP) residues.

3. Li Z. Worldwide regulations of standard values of pesticides for human health risk control: A review / Z. Li, A. Jennings // International Journal of Environmental Research and Public Health. - 2017. - 14 (7). - P. 826.

4. EUROSTAT "Agri-environmental indicator - consumption of pesticides". Electronic resource: http:// ec.europa.eu/eurostat/statistics-explained/index.php.

5. Лебідь Л. Посилюємо захист [Електронний ресурс] / Л. Лебідь. - Режим доступу : http://a7d.com. ua/agropoltika/34852-posilyuyemo-zahist.html.

\section{REFERENCES}

1. Mykhailenko, O.H. (2016). Analiz svitovoho rynku silskohospodarskoi produktsii riznykh vydiv vyrobnytstva v konteksti vymoh kontseptsii staloho rozvytku. Ahrosvit, (4), 43-52 [in Ukrainian].

2. Cunningham, M. (2015). Use of pesticides: benefits and problems associated with pesticides. Food and Chemical Toxicology, 43 (2), 261-269. Retrieved from: www.study.com/academy vegetables for high lipophilic organochlorine pesticide (OCP) residues.

3. Li, Z., \& Jennings, A. (2017). Worldwide regulations of standard values of pesticides for human health risk control: A review. International Journal of Environmental Research and Public Health, 14 (7), 826.

4. EUROSTAT "Agri-environmental indicator - consumption of pesticides". Retrieved from: http://ec.europa. eu/eurostat/statistics-explained/index.php.

5. Lebid L. Posyliuiemo zakhyst [We enhance protection]. Retrieved from: http://a7d.com.ua/agropoltika/34852-posilyuyemo-zahist.html [in Ukrainian].

6. Perelik pestytsydiv i ahrokhimikativ, dozvolenykh do vykorystannia $\vee$ Ukraini [List of pesticides and agro-
6. Перелік пестицидів і агрохімікатів, дозволених до використання в Україні [Електронний ресурс]. Режим доступу : https://agroscience.com.ua.

7. Hematotoxic effects of generic triazole fungicides tebuconazole on Wistar Hannover rats / T. Usenko, V. Shulyak, N. Nedopytanska, M. Prodanchuk // Haematologica. - 2017. - 102. - P. 830-830.

8. Usenko T. Study of acute hematotoxic action of tebuconazole on Wistar Hannover rats / T. Usenko, V. Shulyak // Actual Problems of Transport Medicine. 2018. - 1 (51). - P. 113-121.

9. Guide for the care and use of laboratory animals. (1996) LAR Publication, National Academy Press, USA.

10. OECD Principles of Good Laboratory Practice. ENV/MC/CHEM(98)17 (1998) Environment Directorate Organisation for Economic Cooperation and Development; Paris.

11. Меньшиков В. В. Лабораторные методы исследования в клинике. - М. : Медицина, 1987. - С. 106145.

12. Новикова И. А. Клиническая и лабораторная гематология / И. А. Новикова, С. А. Ходулева. - Минск : Высшая школа, 2013. - 446 с.

chemicals authorized for use in Ukraine]. Retrieved from: https://agroscience.com.ua [in Ukrainian].

7. Usenko, T., Shulyak, V., Nedopytanska, N., \& Prodanchuk, M. (2017). Hematotoxic effects of generic triazole fungicides tebuconazole on Wistar Hannover rats. Haematologica, 102, 830-830.

8. Usenko, T., \& Shulyak V. (2018). Study of acute hematotoxic action of tebuconazole on Wistar Hannover rats. Actual Problems of Transport Medicine, 1 (51), 113-121.

9. Guide for the care and use of laboratory animals. LAR Publication, National Academy Press, USA, 1996.

10. OECD Principles of Good Laboratory Practice. ENV/MC/CHEM(98)17. Environment Directorate Organisation for Economic Cooperation and Development, Paris; 1998.

11. Menshykov, V.V. (1987). Laboratornye metody issledovaniya $v$ klinike [Laboratory methods of research in clinics]. Medytsyna [in Russian].

12. Novikova, I., \& Khoduleva, S. (2013). Klinicheskaya i laboratornaya gematologiya [Clinical and laboratory haematology]. Minsk: Vysshaya shkola [in Russian]. 


\section{ИЗМЕНЕНИЯ ГЕМОПОЭЗА В КОСТНОМ МОЗГЕ И СЕЛЕЗЕНКЕ КРЫС WISTАR НАN КАК МЕХАНИЗМ ГЕМАТОТОКСИЧЕСКОГО ДЕЙСТВИЯ ТЕБУКОНАЗОЛА}

\section{Резюме}

Вступление. Одним из наиболее применяемых действующих веществ фрунгицидов триазольной группы является тебуконазол. Проведенные ранее исследования периферической крови показали его гематотоксическое действие.

Цель исследования - изучить процессы кроветворения в костном мозге и селезенке крыс-самцов Wistar Han после острой интоксикации тебуконазолом техническим, 97 \%.

Методы исследования. Половозрелым крысам-самцам Wistar Han, разделенным на контрольную (0 мг/кг) и 2 экспериментальные группы, однократно внутрижелудочно через зонд была введена токсическая доза тебуконазола - 1700 мг/ке массы тела (1/2 от ЛД 50 . Периферическую кровь исследовали на 0, 1, 3, 7 и 14 постэкспозиционные сутки. Изучали гематологические показатели: количественное содержание эритроцитов и ретикулоцитов, концентрацию гемоглобина, уровень гематокрита, эритроцитарные индексы, количество лейкоцитов и тромбоцитов. Гемограмму с морфологической оценкой клеток крови анализировали в мазках перифрерической крови. Гемопоэз в костном мозге (миелограмма) и селезенке (спленограмма) исследовали на 7 и 14 экспозиционные сутки.

Результаты и обсуждение. Установлено анемизирующее действие, ретикулоцитопению и появление макрофрагов в перифрерической крови. В костном мозге отмечено угнетение эритропоэза с нарушением процессов гемоглобинообразования в нормоцитах, в селезенке развинулось экстрамедуллярное кроветворение. Установлено супрессивное воздействие на клетки эозинофрильного и базофрильного рядов. Наблюдали компенсаторную активизацию нейтрофилопоэза, лимфоцитопоэза и моноцитопоэза в костном мозге.

Вывод. Установлено несколько механизмов гематотоксического действия тебуконазола технического, 97 \%: нарушение гемоглобинообразования, депрессию эритропоэза с патологической регенерацией, развитие экстрамедуллярного кроветворения в селезенке и влияние на некоторые звенья иммунитета.

КЛЮЧЕВЫЕ СЛОВА: гемопоэз; миелограмма; спленограма; экстрамедуллярный эритропоэз; тебуконазол; гематотоксичность.

T. V. Usenko, V. G. Shulyak, M. G. Prodanchuk

L. MEDVED RESEARCH CENTER OF PREVENTIVE TOXICOLOGY, FOOD AND CHEMICAL SAFETY, KYIV

\section{CHANGES OF HEMOPOIESIS IN WISTAR HAN RATS BONE MARROW AND SPLEEN AS A MECHANISM OF HEMATOTOXIC ACTION OF TEBUCONAZOLE}

\section{Summary}

Introduction. One of the most commonly used active substances of the triazole fungicides group is tebuconazole. Preliminary toxicological studies of peripheral blood have shown hematotoxic effect.

The aim of the study - to investigate the hemopoiesis in the bone marrow and spleen of Wistar Han male rats after acute intoxication with technical tebuconazole, $97 \%$.

Research Methods. 15 adult Wistar Han male rats were divided into control $(0 \mathrm{mg} / \mathrm{kg})$ and 2 experimental groups. Toxic dose of tebuconazole $1700 \mathrm{mg} / \mathrm{kg} / \mathrm{bw}\left(1 / 2\right.$ of $\left.L D_{50}\right)$ was administered once orally by gavage. Peripheral blood studies were performed at 0, 1, 3, 7 and 14 postexposure days (PED). Quantitative amount of erythrocytes and reticulocytes, hemoglobin concentration, hematocrit level, erythrocytic indices, number of leukocytes and platelets were examined. Hemogram with morphological assessment of cells were analyzed in peripheral blood smears. Studies of hematopoiesis in the bone marrow (myelogram) and in the spleen (splenogram) were performed at 7 and 14 PED.

Results and Discussion. Anemic effect, reticulocytopenia and the appearance of macrophages in peripheral blood have been established. Depression of erythropoiesis in the bone marrow with a violation of hemoglobin formation in normocytes and the development of extramedullary hemopoiesis in the spleen have been observed. A suppressive action on eosinophilic and basophilic cell types has been defined. Compensatory activation of neutrophilopoiesis, lymphocytopoiesis and monocytopoiesis in bone marrow was shown.

Conclusion. Several mechanisms of hematotoxic action of technical tebuconazole, $97 \%$ : hemoglobin formation impairment, erythropoiesis depression with pathological regeneration, development of extramedular hemopoiesis in the spleen and influence on some parts of immunity have been established.

KEY WORDS: hemopoiesis; myelogram; splenogram; extramedular erythropoiesis; tebuconazole; hematotoxicity.

Адреса для листування: Т. В. Усенко, Науковий центр превентивної токсикології, харчової та хімічної безпеки імені академіка Л. І. Медведя МОЗ України, вул. Героїв Оборони, 6, Київ, 03127, Україна, e-mail: t.usenko.medved@gmail.com. 